\title{
MODEL PEMBELAJARAN KONFLIK KOGNITIF UNTUK MENGATASI MISKONSEPSI PADA MAHASISWA TADRIS FISIKA PROGRAM KUALIFIKASI S.1 GURU MADRASAH
}

\author{
Andi Fadllan
}

\section{Abstrak}

Salah satu faktor umum penyebab rendahnya hasil belajar Fisika yang dicapai siswa adalah terjadinya kesalahan konsep (miskonsepsi) pada diri siswa. Prakonsepsi atau prior knowladge siswa atas konsep Fisika yang dibangun oleh siswa itu sendiri melalui belajar informal dalam upaya memberikan makna atas pengalaman meraka sehari-hari mempunyai peran yang sangat besar dalam pembentukan konsepsi ilmiah.

Miskonsepsi atau salah konsep menunjuk pada suatu konsep yang tidak sesuai dengan pengertian ilmiah atau pengertian yang diterima para pakar dalam bidang itu. Miskonsepsi banyak terjadi pada Fisika khususnya bidang Mekanika. Hal ini pula yang terjadi pada mahasiswa Tadris Fisika program Kualifikasi S.1 Guru Madrasah.

Untuk mengatasi miskonsepsi mahasiswa tersebut, salah satu model pembelajaran yang dapat diterapkan adalah Model Pembelajaran Konflik Kognitif, yakni model pembelajaran di mana mahasiswa dihadapkan pada pertentangan antara prakonsepsi yang telah dimiliki dengan 
konsep ilmiah yang sebenarnya, sehingga mahasiswa akan menyadari kekeliruannya dan mengubah atau melengkapi konsep yang dipahaminya. Model ini terdiri atas tiga fase: (1) mengidentifikasi miskonsepsi beserta latar penyebabnya;(2) mengonfrontasikan gagasan mahasiswa (prakonsepsi) dengan konsepsi ilmiah, dalam upaya menggoyahkan miskonsepsi mahasiswa dan agar mahasiswa menjadi ragu terhadap kebenaran prakonsepsinya; (3) fase konflik, di mana mahasiswa menjadi mengerti dan mau mereorganisasi serta merestrukturisasi gagasannya yang megalami miskonsepsi.

Kata kunci: konflik kognitif, miskonsepsi 


\section{A. Pendahuluan}

Paradigma pembelajaran para guru baik di tingkat dasar maupun mennegah dewasa ini, tampaknya masih dilandasi oleh asumsi bahwa, "pengetahuan dapat dipindahkan secara utuh dari pikiran guru ke pikiran siswa". Menurut paradigma ini, para guru lebih memfokuskan diri pada upaya penuangan pengetahuan kepada para siswanya, tanpa memperhatikan "prior knowledge" siswa atau gagasan-gagasan yang telah ada dalam diri siswa sebelum mereka belajar secara formal di sekolah. Mereka menganggap siswa sebagai botol kosong yang siap diisi oleh apa saja sesuai kehendak pengisinya (dalam hal ini guru). Karenanya, mereka berpikir bahwa setelah proses pembelajaran, di dalam diri siswa terdapat tiruan (copy) pengetahuan seperti yang telah disajikannya dalam interaksi belajar mengajar. Akibatnya siswa hanya menjadi robot-robot yang siap dikendalikan sesuai kehendak gurunya, tidak ada inisiatif dan prakarsa siswa untuk menggali lebih dalam tentang apa yang diajarkan oleh gurunya. Siswa merasa cukup dengan apa yang disampaikan oleh guru, sehingga tidak perlu mempelajari yang lainnya. Kondisi ini, ternyata merupakan salah satu penyebab kurang berhasilnya guru termasuk guru Fisika dalam penyelenggaraan proses pembelajaran, yang tercermin dari masih rendahnya hasil belajar yang dicapai siswa dalam pelajaran Fisika. Selain itu, yang paling terlihat dalam diri siswa adalah ketidakmampuan siswa mengembangkan ide, gagasan, dan kreativitasnya dalam kehidupan sehari-hari. Mereka hanya mampu menghafal rumusrumus fisika tanpa memahami makna fisis apa yang terkandung di dalamnya.

Saat ini, salah satu faktor umum penyebab rendahnya hasil belajar Fisika yang dicapai siswa adalah terjadinya kesalahan konsep (miskonsepsi) pada diri siswa. Prakonsepsi atau prior knowladge siswa atas konsep Fisika yang dibangun oleh siswa itu sendiri melalui belajar informal dalam upaya memberikan makna atas pengalaman meraka sehari-hari mempunyai peran yang sangat besar dalam pembentukan konsepsi ilmiah (Trusmper, 
1990). Prakonsepsi siswa yang pada umumnya bersifat miskonsepsi secara terus-menerus dapat mengganggu pembentukan konsepsi ilmiah. Penelitian ini di negara-negara maju selama dua dasa warsa terakhir menunjukkan bahwa salah satu sumber kesulitan belajar siswa adalah adanya miskonsepsi siswa (van den Berg, 1991). Ausubel (1978) juga mengemukakan bahwa proses pembelajaran yang tidak menghiraukan prakonsepsi siswa, akan mengakibatkan miskonsepsi-miskonsepsi siswa semakin kompleks, sehingga semakin sulit untuk mengubahnya.

Sehubungan dengan hal di atas, perlu dilakukan reorientasi dalam paradigma dan proses pembelajaran fisika. Para pakar dan praktisi pendidikan Fisika, khususnya guru Fisika perlu beralih dari model pembelajaran konvensional menuju model pembelajaran yang berdasarkan atas paradigma konstruktivisme, dengan asumsi dasar bahwa "pengetahuan dibangun dalam pikiran pebelajar" (Bodner, 1986). Para konstruktivis memandang perlu pergeseran secara tajam dari individu-individu yang berdiri di depan kelas sebagai guru. Suatu pergeseran dari seseorang yang mengajar menjadi seorang fasilitator, mediator, dan motivator pembelajaran, dari mengajar sebagai proses pembebanan menuju mengajar sebagai proses negosiasi, dari interaksi satu araha menuju interaksi multiarah. Mengajar bukanlah kegiatan memindahkan pengetahuan dari guru ke siswa, melainkan suatu kegiatan yang memungkinkan siswa untuk mengonstruksi sendiri pengetahuannya.

Menurut pandangan konstruktivisme, belajar pada hakikatnya merupakan proses modifikasi gagasan-gagasan yang telah ada pada diri pebelajar. Belajar adalah pembentukan pengertian atas pengalaman-pengalaman dalam hubungannya dengan pengetahuan yang telah dimiliki sebelumnya (prior knowledge). Belajar terjadi melalui konstruksi dan elaborasi struktur kognitif atas dasar pengalaman. Sebagai implikasi dari konseptualisasi ini, maka pikiran pebelajar harus dipandang sebagai jaringan ide yang kaya dan bervariasi, dan bukan sebagai tabularasa. Penekanan dalam belajar bukan pada korespondensi dengan suatu otoritas eksternal, tetapi pada penyusunan sche- 
mata-skemata atau struktur kognitif yang koheren dan berguna bagi pebelajar. Orientasi dalam proses evaluasi pembelajaran seyogyanya bergeser dari "kebenaran siswa melakukan replikasi atas apa yang dikerjakan guru" menuju "suksesnya siswa mengorganisasi pengalaman mereka" (Driver, 1988).

Berdasarkan uraian di atas, maka perlu dirancang dan dikembangkan suatu model pembelajaran Fisika yang dilandasi oleh paradigma konstruktivisme. Model pembelajaran ini dirancang dengan menggunakan prior knowledge siswa sebagai basis, dan terutama diarahkan untuk memperbaiki miskonsepsi siswa menjadi konsepsi ilmiah, yang pada akhirnya akan bermuara pada peningkatan kualitas proses dan hasil belajar siswa. Model pembelajaran ini mengandung prosedur ilmiah, spesifikasi hasil belajar, spesifikasi lingkungan belajar, kriteria penampilan, dan langkah-langkah serta prosedur pembelajarannya.

Salah satu model pembelajaran yang dapat dikembangkan berdasarkan atas paradigma konstruktivisme adalah model konflik kognitif (cognitive conflict model). Model konflik kognitif didasarkan atas konstruktivisme Piagetian yang memberi tekanan pada pengkonstruktisian pengetahuan melalui proses intraindividual (Roth \& Roychoudhury, 1993). Pada model ini, siswa prakonsepsi siswa dibenturkan dengan konsepsi ilmiah sehingga muncul keraguan dalam diri siswa sebagai modal menuju perbaikan pemahaman konsep.

Terjadinya miskonsepsi pada diri siswa tidak terlepas dari konsep yang dimiliki oleh gurunya, yang mungkin mengandung miskonsepsi. Tulisanini merupakan refleksi dari pelaksanaan pembelajaran yang penulis lakukan terhadap mahasiswa Tadris Fisika Program Kualifikasi S.1 Guru Madrasah. Tulisan dimaksudkan untuk menemukan miskonsepsi yang terjadi pada mahasiswa yang notabene adalah seorang guru baik di MTs maupun MA sekaligus menemukan pemecahannya. 


\section{B. Pengertian Miskonsepsi}

Miskonsepsi atau salah konsep menunjuk pada suatu konsep yang tidak sesuai dengan pengertian ilmiah atau pengertian yang diterima para pakar dalam bidang itu (Suparno, 2005). Novak (1984) mendefinisikan miskonsepsi sebagai suatu interpretasi konsep-konsep dalam suatu pernyataan yang tidak dapat diterima. Sementara itu, Feldsine (1987) menemukan miskonsepsi sebagai suatu kesalahan dan hubungan yang tidak benar antara konsep-konsep. Hanya Fowler (1987) yang menjelaskan lebih rinci arti miskonsepsi. Fowler memandang miskonsepsi sebagai pengertian yang tidak akurat akan konsep, penggunaan konsep yang salah, klasifikasi contoh-conroh yang salah, kekacauan konsep-konsep yang berbeda, dan hubungan hirarkis konsep-konsep yang tidak benar. Dengan demikian, miskonsepsi dapat berupa konsep awal (prakonsepsi), kesalahan, hubungan yang tidak benar antara konsep-konsep, gagasan intuitif atau pandangan yang naif.

Meski istilah miskonsepsi telah menjelaskan adanya kesalahan atau kekacauan konsep, namun kebanyakan peneliti modern lebih memilih menggunakan istilah "konsep alternatif" daripada miskonsepsi. Ada beberapa alasan mengapa istilah konsep alternatif lebih dipilih daripada miskonsepsi. Pertama, konsep alternatif lebih merujuk pada penjelasan berdasarkan pengalaman yang dikonstruksi siswa. Kedua, istilah tersebut lebih memberikan penghargaan intelektual kepada siswa yang memberikan gagasan tersebut. Ketiga, seringkali konsep alternatif secara kontekstual masuk akal dan berguna untuk menjelaskan beberapa persoalan yang dihadapi siswa (Wandersee, Mintzes, dan Novak, 1994). Dengan menggunakan istilah ini, gagasan dan pandangan siswa mendapat penghargaan dan tidak ditolak mentah-mentah, sehingga tidak berdampak terhadap motivasi belajar mereka untuk mengonstruksi konsep yang benar.

Namun beberapa peneliti yang lain lebih suka menggunakan istilah miskonsepsi dengan beberapa alasan: (1) Istilah miskonsepsi sudah mempunyai makna bagi orang wam; (2) 
Dalam pendidikan sains, istilah ini sudah membawa pengertianpengertian tertentu sesuai dengan pemikiran saintifik saat ini; dan (3) Istilah miskonsepsi mudah dimengerti baik oleh guru dan orang awam (Wandersee, Mintzes, dan Novak, 1994).

Menurut Clement (1987), jenis miskonsepsi yang paling banyak terjadi adalah konsep awal (prakonsepsi) yang dibawa oleh siswa ke dalam kelas formal. Dalam kehidupan seharihari, mereka telah mengonstruksi konsep-konsep tersebut sesuai dengan kemampuan daya nalar dan analisisnya. Di satu sisi, konstruksi konsep oleh siswa sangat penting dalam membantu memecahkan persoalan tertentu. Misalnya, prakonsepsi siswa tentang massa dan berat. Kebanyakan siswa mengalami kesulitan untuk membedakan antara pengertian massa dan berat.

\section{Mengapa Muncul Miskonsepsi?}

Berdasarkan beberapa hasil penelitian, miskonsepsi terjadi tidak hanya di tingkat siswa sekolah dasar hingga menengah, tetapi juga menghinggapi mahasiswa di perguruan tinggi (GilPerez, 1990; Brown, 1989). Bahkan, misonsepsi juga banyak terjadi pada guru-guru, sehingga menyebabkan miskonsepsi pada diri siswa yang diajarnya. Di samping itu, miskonsepsi juga muncul pada buku-buku teks yang digunakan oleh siswa dan guru. Miskonsepsi pada buku ini biasanya dalam bentuk pengertian, istilah, contoh, gambar, grafik, hingga penerapannya.

Menurut filsafat konstruktivisme, pengetahuan itu dibentuk atau dikonstruksi oleh siswa sendiri ketika berhubungan dengan lingkungan, tantangan, dan bahan yang dipelajari (Suparno, 1997). Oleh karena pengetahuan adalah konstruksi siswa atau mahasiswa sendiri (tentunya dengan bantuan guru/ pendidik/dosen), maka miskonsepsi sangat mungkin terjadi, meskipun diberi bahan atau materi pelajaran yang sama dengan cara yang sama oleh guru. Ketika guru menyampaikan bahan atau materi itulah, siswa mengonstruksi konsep-konsep yang ada. Utuh-tidaknya konsep yang dikonstruksi bergantung pada kemampuannya dan gagasan-gagasan yang kebetulan dialaminya. 
Dalam filsafat konstruktivisme, tampak jelas bahwa miskonsepsi merupakan suatu hal yang wajar yang terjadi dalam proses belajar. Munculnya miskonsepsi ini juga menunjukkan bahwa konsep itu dibangun sendiri oleh siswa, bukan dibentuk dan dilimpahkan oleh guru kepada siswa. Guru hanya dapat membantu siswa untuk "mengetahui", tidak memaksa siswa untuk "mengetahui".

Terjadinya miskonsepsi pada diri siswa disebabkan oleh beberapa faktor, di antaranya: (1) Prakonspesi atau konsepawal siswa; (2) pemikiran asosiatif; (3) pemikiran humanistik; (4) reasoning yang tida lengkap/utuh; (5) intuisi yang salah; (6) tahap perkembangan kognitif; (7) kemampuan; dan (8) minat belajar.

Prakonsepsi atau konsep awal siswa sebelum masuk ke dalam pembelajaran formal seringkali mengandung kesalahan sehingga menyebabkan munculnya miskonsepsi. Prakonsepsi ini biasanya diperoleh siswa dari orang tua, teman, sekolah awal, dan pengalaman di lingkungannya. Prakonsepsi ini menunjukkan bahwa pikiran anak sejak lahir tidak diam, tetapi terus aktif untuk memahami sesuatu. Dalam pengertian Piaget, pikiran anak terus menyesuaikan dir dengan situasi yang dialaminya. Semakin banyak miskonsepsi pada orang tua, tetangga, teman, dan sekolah awal, maka akan semakin banyak pula prakonsepsi siswa yang salah.

Asosiasi siswa terhadap istilah-istilah keseharian kadangkadang membuat miskonsepsi (Marioni, 1989). Kebanyakan siswa mengasosiasikan kerja dengan energi. Jika ada energi yang diperlukan untuk melakukan sesuatu pastilah ada kerja. Asosiasi ini tidaklah benar jika ditinjau dalam fisika. Kerja tidak selalu identik dengan energi. Ketika seseorang mendorong mobil dengan menggunakan energi yang besar, tetapi ternyata mobil tetap berada di posisinya, maka orang tersebut dikatakan tidak melakukan kerja, karena mobil tida berpindah posisi. Pengertian yang berbeda dari kata-kata antara guru dan siswa juga dapat menyebabkan misonsepsi (Marshall dan Gilmour, 1990).

Dalam banyak hal, siswa seringkali memandang semua benda dari pandangan manusiawi. Hal ini disebut pandangan 
humanistik. Benda-benda, situasi, dan tingkah laku benda dipahami seperti tingkah laku manusia yang hidup. Sementara itu, menurut Comins (1993), reasoning atau alasan siswa yang tidak lengkap juga dapat menyebabkan miskonsepsi. Alasan yang tidak lengkapdapat disebabkan karena informasi yang diterima tidak lengkap.

Faktor penyebab miskonsepsi lainnya adalah adanya intuisi yang salah. Intuisi adalah suatu perasaan dalam diri seseorang yang secara spontan mengungkapkan sikap atau gagasannya tentang sesuatu sebelum secara obyektif dan rasional diteliti. Misalnya ketika siswa diberikan dua buah benda yang dijatuhkan dari ketinggian tertentu, maka secara intuitif siswa akan mengatakan bahwa benda yang lebih besar akan jatuh lebih cepat daripada yang kecil. Pemikiran intuitif ini biasanya berasal dari pengamatan terhadap benda atau kejadian yang terusmenerus, sehingga secara spontan, jika menghadapi persoalan fisika tertentu, yang muncul dalam benak siswa adalah pemahaman spontan tersebut.

Perkembangan kognitif siswa yang tidak sesuai dengan bahan yang dipelajari dapat pula menyebabkan misonsepsi. Secara umum, siswa yang berada dalam tahap operational concrete akan sulit memahami dan seringkali salah mengerti tentang sesuatu yang abstrak. Misalnya, ketika siswa mempelajari tentang konsep dualisme sifat cahaya sebagai gelombang dan partikel. Siswa sulit memahami bagaimana cahaya dipandang sebagai partikel. Lalu jika partikel dianggap berbentuk bola, maka cahaya dapat menggelinding layaknya bola. Inilah pemikiran yang muncul jika siswa dalam tahap operational concrete memahami konsepkonsepyang abstrak.

Faktor penyebab lain dari munculnya miskonsepsi adalah kemampuan dan minat belajar siswa. Semakin baik kemampuan siswa dalam memahami suatu konsep dan semakin berminat mereka terhadap konsep yang sedang dipelajari, maka semakin kecil kemungkinan munculnya miskonepsi. Kalaupun muncul miskonsepsi, hal itu hanyalah proses menuju pemahaman yang lebih utuh terhadap konsep yang dimaksud. Siswa yang bermi- 
nat akan berusaha mencari tahu lebih dalam daripada mereka yang tidak berminat.

Selain oleh siswa, miskonsepsi juga disebabkan oleh guru. Guru yang tidak menguasai atau mengerti bahan secara tida benar akan menyebabkan siswa mendapatkan miskonsepsi. Penelitian tentang miskonsepsi Sains-Fisikadi tingkat SD dan SMP menunjukkan bahwa guru kurang menguasai bahan yang diajarkan (Suparno, 2005). Di beberapa wilayah di Indonesia, guru Fisika tidak memiliki latar belakang pendidikan Fisika atau Fisika, akibatnya konsep yang dimiliki cenderung seadanya. Hal ini terjadi karena memang tidak ada guru lulusan pendidikan Fisika yang tersedia.

Dalam banyak kasus, kondisi tersebut masih diperparah dengan sikap guru Fisika yang cenderung diktator dan otoriter. Cukup banyak guru Fisika yang mengajar hanya dengan berbicara dan menulis di papan tulis (Suparno, 2005). Mereka jarang membuat eksperimen, jarang mendiskusikan bahan dengan siswa, apalagi meminta siswa mengungkapkan konsep dengan bahasanya sendiri (Arons, 1981). Cukup banyak guru yang cepat lari pada rumusan matematis dan bukan pada konsep, karena dirasa lebih mudah.

Faktor penyebab miskonsepsi selain siswa dan guru adalah buku teks, konteks (pengalaman), dan cara mengajar. Pada tabel 1 berikut akan ditampilkan penyebab miskonsepsi pada siswa.

Tabel 1. Penyebab Miskonsepsi Siswa

\begin{tabular}{|l|l|}
\hline Sebab Utama & \multicolumn{1}{|c|}{ Sebab khusus } \\
\hline Siswa & - Prakonsepsi \\
& - Pemikiran asosiatif \\
& - Pemikiran humanistik \\
& - Reasoning yang tidak lengkap \\
& - Thtuisi yang salah \\
& - Kemap perkembangan kognitif siswa \\
& - Minat belajar siswa \\
\hline
\end{tabular}




\begin{tabular}{|c|c|}
\hline Guru & $\begin{array}{l}\text { - Tidak menguasai bahan, tidak kompeten } \\
\text { - Bukan berlatar belakang ilmu fisika } \\
\text { - Tidak mengajak siswa mengungkapkan } \\
\text { ide/gagasan } \\
\text { - Relasi guru-siswa tidak baik }\end{array}$ \\
\hline Buku teks & $\begin{array}{l}\text { - Penjelasan keliru } \\
\text { - Salah tulis, terutama dalam rumus } \\
\text { - Tingkat kesulitan buku terlalu tinggi bagi } \\
\text { siswa } \\
\text { - Siswa tidak tahu membaca buku teks } \\
\text { - Buku fiksi sains kadang-kadang } \\
\text { - konsepnya menyimpang } \\
\text { - Kartun sering memuat miskonsepsi }\end{array}$ \\
\hline Konteks & $\begin{array}{l}\text { - Pengalaman siswa } \\
\text { - } \text { Bahasa shari-hari berbeda } \\
\text { - Teman diskusi yang salah } \\
\text { - Keyakinan dan agama } \\
\text { - Penjelasan orang lain yang keliru } \\
\text { - Konteks hidup siswa(TV, radio, film) yang } \\
\text { keliru } \\
\text { - Perasaan senang atau tidak, bebas atau } \\
\quad \text { tertekan }\end{array}$ \\
\hline $\begin{array}{l}\text { Cara } \\
\text { Mengajar }\end{array}$ & $\begin{array}{l}\text { - Hanya berisi ceramah dan menulis } \\
\text { - Langsung ke dalam bentuk matematis } \\
\text { - Tidak mengungkapkan miskonsepsi siswa } \\
\text { - Tidak mengoreksi PR yang salah } \\
\text { - Model analogi } \\
\text { - Model praktikum } \\
\text { - Model diskusi } \\
\text { - Model demonstrasi yang sempit } \\
\text { - Non-multiple intelligences }\end{array}$ \\
\hline
\end{tabular}

\section{Miskonsepsi dalam Pembelajaran Fisika}

Miskonsepsi dalam bidang Fisika banyak terjadi. Wandersee, Mintzes, dan Novak (1994), dalam artikelnya Research on Alternative Conceptions on Science, menjelaskan bahwa konsep alternatif atau miskonsepsi terjadi dalam semua bidang Fisika. Dari 700 studi tentang konsep alternatif bidang fisika, terdapat 300 
yang meneliti tentang misonsepsi dalam mekanika; 159 tentang listrik; 70 tentang panas, optika dan sifat-sifat materi; 35 tentang bumi dan antariksa; serta 10 studi tentang fisika modern. Dari studi tersebut terlihat bahwa bidang mekanika berada pada urutan teratas dari bidang-bidang lainnya. Meski demikian, tidak berarti bahwa miskonsepsi hanya terjadi pada mekanika, tetapi sejauh ini banyak penelitian yang dilakukan dalam bidang mekanika. Hal ini cukup beralasan karena mekanikamenjadi materi awal dan utama di tingkatan sekolah menengah dan di perguruan tinggi.

Berdasarkan hasil pengamatan terhadap konsep mahasiswa Tadris Fisika Program Kualifikasi S.1 Guru Madrasah, terdapat beberapa miskonsepsi khususnya dalam bidang mekanika. Berikut diuraikan lebih detail mengenai miskonsepsi tersebut.

1. Sebagian besar mahasiswa masih beranggapan bahwa jika dua benda bergerak dalam waktu dan percepatan yang sama, maka kedua benda tersebut akan menempuh jarak yang sama pula. Mahasiswa lupa adanya kecepatan awal. Padahal kecepatan awal inilah yang menyebabkan jarak yang ditempuh kedua benda berbeda. Jika keduanya memiliki kecepatan awal yang sama, maka tentu jarak yang ditempuh akan sama, tetapi jika kecepatan awal keduanya berbeda, maka jarak yang ditempuh pastinya akan berbeda.

2. Dalam rumus untuk menentukan jarak benda yang bergerak lurus berubah beraturan (GLBB),

$$
S=v_{0} \cdot t+\frac{1}{2} t^{2}
$$

tampak bahwa kecepatan awal $\left(v_{0}\right)$ ikut menentukan jarak suatu benda.

3. Pada gerak parabola, mahasiswa masih beranggapan bahwa kecepatan benda di puncak adalah nol, karenanya percepatan benda juga harus nol. Mereka tidak berpikir mengapa kecepatan benda di puncak menjadi nol. Seanainya tidak ada percepatan gravitasi bumi, maka benda yang dilempar ke atas selamanya akan bergerak naik ke atas sehingga kecepa-

150 Jurnal PHENOMENON, Volume 2 Nomor 1, November 2011 
tan benda tidak akan berkurang, apalagi sampai bernilai nol. Jadi, meskipun kecepatan benda bernilai nol saat dipuncak, percepatan gravitasi tetap bekerja pada benda tersebut.

4. Ketika ditanyakan kepada mahasiswa, apakah terdapat gaya yang bekerja pada buku yang diletakkan di atas meja? Mayoritas mahasiswa menjawab "tidak ada". Mereka beralasan bahwa buku diam/tidak bergerak, sehingga tidak ada gaya yang bekerja padanya. Mereka tidak memahami bahwa ada gaya gravitasi yang bekerja pada buku tersebut. Mahasiswa juga masih beranggapan bahwa hukum I Newton menyatakan suatu benda akan berada dalam keadaan diam atau bergerak dengan laju konstan sepanjang garis lurus, jika tidak ada gaya yang bekerja padanya. Padahal, pernyataan yang benar adalah suatu benda akan berada dalam keadaan diam atau bergerak dengan laju konstan sepanjang garis lurus, jika resultan gaya yang bekerja pada benda sama dengan nol. Mahasiswa masih belum mampu membedakan antara "tidak ada gaya" dengan "resultan gaya sama dengan nol".

5. Pada hukum III Newton, mahasiswa berpikir bahwa gaya aksi bekerja atau muncul lebih dahulu daripada gaya reaksi. Ketika tangan memukul meja, maka gaya aksi diberikan oleh tangan kepada meja. Sedangkan gaya reaksi muncul sesudahnya, yaitu gaya yang diberikan oleh meja kepada tangan. Padahal jika menggunakan konteks kerangka referensi, sebenarnya tidak tepat jika gaya aksi pada kasus tersebut adalah gaya yang diberikan tangan kepada meja. Asumsi ini digunakan hanya untuk memudahkan memahami adanya gaya aksi-reaksi, padahal sejatinya jika menggunakan kerangka referensi yang lain, kita bisa mengatakan meja lah yang memberikan aksi kepada tangan kita. Jadi, "gaya aksi" dan "gaya reaksi" sebenarnya merupakan dua buah gaya yang muncul secara bersamaan, tidak dapat dikatakan bahwa salah satu dari kedua gaya tersebut adalah gaya aksi, sementara yang lainnya adalah gaya reaksi.

6. Masih pada hukum III Newton, ketika diberikan kasus benda yang digantung dengan menggunakan tali sebagaimana 
gambar berikut.

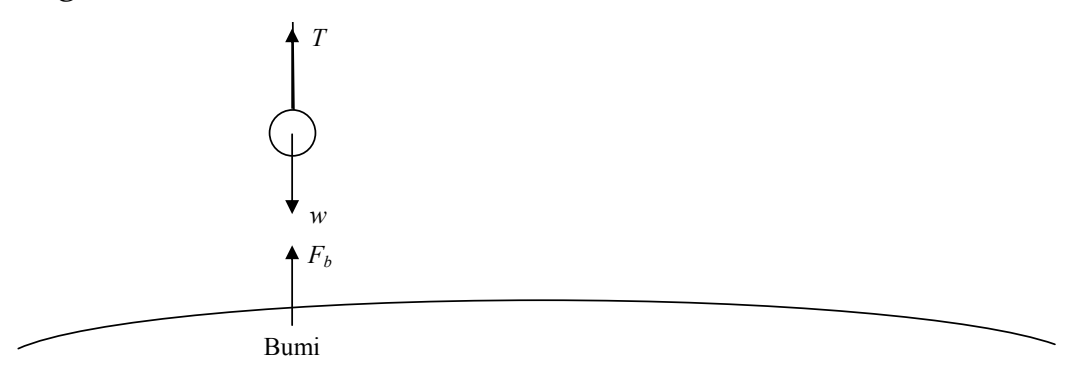

seluruh mahasiswa beranggapan, bahwa pasangan gaya aksi-reaksi adalah gaya tegang tali $(T)$ dan gaya berat oleh gravitasi bumi $(w)$. Padahal pasangan aksi-reaksi sebenarnya adalah $w$ dan $F_{b}$ (gaya pada bumi oleh tarikan benda). Besarnya $w$ dan $F_{b}$ sama tetapi berlawanan arah. Resultan gaya tegang tali $(T)$ dan gaya berat oleh gravitasi bumi $(w)$ sama dengan nol, bukan karena pasangan aksi-reaksi, tetapi karenan keseimbangan. Gaya aksi-reaksi merupakan pasangan gaya yang bekerja pada dua buah benda yang berbeda. Jika "aksi" disebabkan oleh A yang bekerja pada B, maka "reaksi" disebabkan oleh B yang bekerja pada A.

Dari beberapa miskonsepsi yang telah dikemukakan tersebut, beberapa faktor yang kemungkinan penyebab miskonsepsi pada diri mahasiswa yang notabene seorang guru Fisika atau IPA, antara lain : (1) buku pelajaran.Buku pelajaran yang memuat rumus atau uraian materi yang salah. Beberapa buku atauLKS yang beredar di sekolah/madrasah memang mengandung banyak miskonsepsi. Mulai dari penulisan istilah dan pengertiannya, penggunaan satuan, penggambaran vektor gaya, hingga contoh penerapannya; (2) kesalahan bahasa.Dalam banyak kasus kesalahan bahasa ini muncul akibat budaya masyarakat yang terlanjur salah-kaprah dalam mendefinisikan sesuatu secara ilmiah; (3) intuisi yang salah.Ini merupakan faktor yang paling dominan mengakibatkan miskonsepsi di kalangan mahasiswa. Biasanya mereka malu untuk bertanya kepada teman guru lainnya yang dianggap lebih tahu. Karenanya, prinsip ko-

152 Jurnal PHENOMENON, Volume 2 Nomor 1, November 2011 
legalitas dan rasa ingin tahu perlu dipupuk dalam diri mahasiswa (guru).

\section{E. Model Konflik Kognitif untuk Mengatasi Miskonsepsi}

Sebagai seorang guru, mahasiswa Tadris Fisika program Kualifikasi S.1 tentunya memiliki prior knowledge atau prakonsepsi yang cukup baik. Meski berlatar belakang pendidikan bukan Fisika atau IPA, setidaknya dalam keseharian mereka telah mempelajari dan bergelut dengan materi Fisika. Mau tidak mau mereka dipaksa untuk menguasai materi lebih dalam dan lebih dahulu daripada siswanya. Oleh karena prior knowledge mahasiswa yang cukup baik, maka dalam pembelajaran mata kuliah yang ditempuh oleh mahasiswa, khususnya mata kuliah Fisika Dasar, seyogyanya dipilih model pembelajaran yang mampu memenuhi kebutuhan mereka. Jika menggunakan metode ceramah, tentunya akan mengakibatkan mahasiswa lebih cepat jenuh. Di samping itu, mereka merasa dianggap hanya sebagai botol kosong yang perlu diisi materi sesuai keinginan dosen. Jika ini terjadi, maka pastinya hubungan antara dosen dan mahasiswa akan berjalan tidak baik.

Beberapa model pembelajaran dapat diterapkan untuk mengatasi miskonsepsi yang terjadi sekaligus tidak menempatkan mahasiswa sebagai mahasiswa fresh graduated yang perlu diatur dan diarahkan terus-menerus. Salah satu model pembelajaran yang akan mampu mengatasi kebutuhan mahasiswa adalah Model Konflik Kognitif.

Model Konflik Kognitif merupakan model pembelajaran di mana mahasiswa dihadapkan pada pertentangan antara prakonsepsi yang telah dimiliki dengan konsep ilmiah yang sebenarnya. Dengan memunculkan pertentangan ini diharpakan mahasiswa akan menyadari kekeliruannya dan mengubah atau melengkapi konsep yang dipahaminya.

Ada tiga fase pokok dalam model konflik kognitif. Pertama, identifikasi miskonsepsi beserta latar penyebabnya. Hal ini perlu dilakukan untuk mengetahui pada bagian mana dan pada level 
apa miskonsepsi itu terjadi. Selain itu, dengan memahami penyebab munculnya miskonsepsi, dosen dapat mencari alternatif pemecahannya secara cepat. Kedua, mengonfrontasikan gagasan mahasiswa (prakonsepsi) dengan konsepsi ilmiah, dalam upaya menggoyahkan miskonsepsi mahasiswa dan agar mahasiswa menjadi ragu terhadap kebenaran prakonsepsinya. Dengan adanya keraguan tersebut akan memunculkan rasa ingin tahu untuk belajar lebih dalam. Ketiga, fase konflik yang merupakan titik sentral dari pengubahan miskonsepsi mahasiswa menjadi konsepsi ilmiah. Hanya melalui fase konfliklah mahasiswa akan menjadi mengerti dan mau mereorganisasi serta merestrukturisasi gagasannya yang miskonsepsi (Dreypus, 1990).

Dari beberapa miskonsepsi yang muncul pada mahasiswa program Kualifikasi, beberapa langkah model pembelajaran KonflikKognitif yang dapat diterapkan adalah sebagai berikut.

1. Mengidentifikasi miskonsepsi dan penyebabnya. Dari beberapa miskonsepsi di atas, penyebab utama miskonsepsi mahasiswa adalah pembacaan mereka terhadap referensi yang digunakan. Kemampuan mahasiswa memahami teks yang berbeda dengan konteks (pengalaman) telah menimbulkan keraguan, namun kebanyakan mahasiswa tidak memedulikannya. Bahkan mereka menghindarinya dengan langsung menyampaikan rumus matematis kepada siswa dan memberikan contoh soal-soal latihan. Selain itu, materi referensi yang digunakan mengandung banyak miskonsepsi, terlebih jika referensi yang digunakan hanya berupa lembaran-lembaran materi dan kumpulan soal yang sering disebut "Lembar Kerja Siswa".

2. Mengonfrontaskan prakonsepsi mahasiswa dengan konsepsi ilmiah.

a. Pada kasus pertama, dosen meminat mahasiswa memikirkan bagaimanajika kecepatan awal kedua benda sama dengan nol. Kemudian ditanyakan pula bagaimana jika kecepatan awal kedua benda berbeda, apakah jarak yang ditempuh benda dengan percepatan dan waktu yang sama akan 
bernilai sama?

b. Mahasiswa diminta untuk melihat bagaimana sebuah benda dilemparkan ke atas. Kemudian dosen bertanya kepada mahasiswa, Andai tidak ada gaya gravitasi, apa yang terjadi pada benda yang dilempar ke atas? Bagaimana kecepatan benda tersebut? Apakah benda yang dilempar ke atas akan memiliki puncak? Jika ada gaya gravitasi, apakah benda yang dilempar ke atas akan memiliki puncak? Mengapa "puncak tertinggi" ada? Apa yang menyebabkannya? Berapa kecapatan benda di puncak?

c. Dosen menunjukkan penghapus yang diletakkan di atas meja, kemudian bertanya, adakah gaya yang bekerja pada penghapus tersebut? Mengapa penghapus diam di atas meja? Selanjutnya dosen menekan kedua ujung penghapus dengan besar yang sama, kemudian bertanya lagi, adakah gaya yang bekerja pada penghapus? Mengapa pengahpus tetap diam di atas meja? Adakah perbedaannya dengan yang sebelumnya (penghapus tidak ditekan)? Di akhir demonstrasi tersebut, dosen bertanya kembali, apakah penghapus memerlukan gaya untuk diam?

d. Dosen mendemonstrasikan memukul buku, kemudian bertanya kepada mahasiswa, siapakah yang memukul? Manakah gaya aksi, dan mana pula gaya reaksinya? Apakah bisa dikatakan bahwa buku yang memukul tangan kita? Apakah tangan merasakan sakit setelah memukul atau pada saat memukul?

e. Mahasiswa diminta menggambarkan gaya-gaya yang ada dalam sistem benda yang digantung dengan tali dan menentukan pasangan gaya aksi-reaksi tersebut, kemudian diminta mengemukakan alasannya. Untuk menimbulkan 
keraguan, dosen bertanya, apakah pasangan aksireaksi bekerja pada benda yang sama ataukah berbeda? Jika berbeda, apakah ada tiga atau lebih benda yang bekerja untuk pasangan tersebut?

3. Memperkuat konflik. Langkah ini dillakukan untuk semakin menumbuhkan keraguan mahaiswa terhadap konsep yang mereka pahami. Kemudian mereka diajak untuk menemukan konsep yang sebenarnya.

Ketiga fase Model Konflik Kognitif tersebut dapat terlaksana dengan baik jika dosen memiliki kemampuan untuk bertanya lanjut. Keterampilan ini merupakan salah satu keterampilan dasar mengajar yang harus dikuasi oleh dosen. Di samping itu, pemilihan dan penggunaan istilah atau kata yang tepat akan mendukung komunikasi dan interaksi antara dosen dan mahasiswa. Hasil yang diharapkan muncul pada mahasiswa setelah mengikuti pembelajaran dengan model ini adalah terbentuknya konsep baru yang bebas dari miskonsepsi. Selain itu, menumbuhkan budaya ragu pada sesuatu dan rasa ingin tahu terhadap segala sesuatu. Rasa ingin tahu inilah yang akan mendorong mahasiswa untuk belajar secara lebih serius.

\section{F. Penutup}

Miskonsepsi atau salah konsep menunjuk pada suatu konsep yang tidak sesuai dengan pengertian ilmiah atau pengertian yang diterima para pakar dalam bidang itu (Suparno, 2005). Miskonsepsi banyak terjadi pada Fisika khususnya bidang Mekanika. Hal ini pula yang terjadi pada mahasiswa Tadris Fisika program Kualifikasi S.1 Guru Madrasah.

Untuk mengatasi miskonsepsi mahasiswa tersebut, salah satu model pembelajaran yang dapat diterapkan adalah Model Pembelajaran Konflik Kognitif, yakni model pembelajaran di mana mahasiswa dihadapkan pada pertentangan antara prakonsepsi yang telah dimiliki dengan konsep ilmiah yang sebena-

156 Jurnal PHENOMENoN, Volume 2 Nomor 1, November 2011 
rnya, sehingga mahasiswa akan menyadari kekeliruannya dan mengubah atau melengkapi konsep yang dipahaminya. Model ini terdiri atas tiga fase: (1) mengidentifikasi miskonsepsi beserta latar penyebabnya;(2) mengonfrontasikan gagasan mahasiswa (prakonsepsi) dengan konsepsi ilmiah, dalam upaya menggoyahkan miskonsepsi mahasiswa dan agar mahasiswa menjadi ragu terhadap kebenaran prakonsepsinya; (3) fase konflik, di mana mahasiswa menjadi mengerti dan mau mereorganisasi serta merestrukturisasi gagasannya yang megalami miskonsepsi. 


\section{DAFTAR PUSTAKA}

Clement, J. 1987. Overcoming Students' Misconception in Physics: the Role of Anchoring Intuition and Analogical Validity. In Proceeding of Second International Seminar on Misconceptions and Educational Strategies in Science and Mathematics, Vol. III, 84 - 97. Ithaca. NY: Cornell University.

Comins, N. 1993. Source of Misconceptions in Astronomy. In Proceeding of Third International Seminar on Misconceptions and Educational Strategies in Science and Mathematics. Ithaca. NY: Misconceptions Trust, August 1 - 4.

Dreyfus, Amos, et. all. 1990. Applying the "Cognitive Conflict" Strategy for Conceptual Change, Some Implications, Difficulties, and Problem. Journal of Science Education.

Feldsine, J. 1987. Distinguishing Students Misconceptions from Alternate Conceptual Frameworks through The Construction of Concept Maps. In Proceeding of Second International Seminar on Misconceptions and Educational Strategies in Science and Mathematics, Vol. I, 177 - 181. Ithaca. NY: Cornell University.

Gil-Perez \& Carrascoa. 1990. What to do about Science Misconceptions. Science Education.

Novak \& Gowin. 1984. Learning How to Learn. Cambridge: University Press.

Sadia, I Wayan. 1997. Efektivitas Strategi Konflik Kognitif dalam Mengubah Miskonsepsi Siswa (Suatu Studi Eksperimental dalam Pembelajaran Konsep Energi, Usaha, dan gaya Gesekan di SMU Negeri 1 Singaraja). Aneka Widya, No. 4 Th. XXX Juli 1997. STKIP Singaraja.

158 Jurnal PHENOMENON, Volume 2 Nomor 1, November 2011 
Suparno, Paul. 1997. Filsafat Konstruktivisme dalam Pendidikan. Yogyakarta: Kanisius.

Suparno, Paul. 2005. Miskonsepsi \& Perubahan Konsep Pendidikan Fisika. Jakarta: Grasindo.

Van den Berg, Euwe. 1991. Miskonsepsi Fisika dan Remediasi. Salatiga: Universitas Kristen Satya Wacana

Wandersee, Mintzes, \& Novak. 1994. Research on Alternative Conceptions in Science. Handbook of Research on Science Teaching and Learning, eds. Dorothy L. Gabel. New York: Macmillan Publishing Company. 